\title{
THE VIEWS AND EXPERIENCES OF LGBTQ+ PEOPLE REGARDING MIDWIFERY CARE: A SYSTEMATIC REVIEW OF THE INTERNATIONAL EVIDENCE
}

Edward McCann ${ }^{\mathrm{a}^{*}}$, Michael Brown ${ }^{\mathrm{b}}$, Caroline Hollins-Martin' ${ }^{\mathrm{c}}$, Karen Murray ${ }^{\mathrm{d}}$, Freda McCormick $^{\mathrm{b}}$

a School of Nursing and Midwifery, University of Dublin, Trinity College, Dublin, Ireland. ${ }^{\mathrm{b}}$ School of Nursing and Midwifery, Queen's University Belfast, 97 Lisburn Road, Belfast, Northern Ireland.

${ }^{c}$ School of Nursing \& Midwifery, Edinburgh Napier University, Scotland

${ }^{\mathrm{d}}$ Royal College of Midwives, Northern Ireland.

*Corresponding author:

Dr Edward McCann

School of Nursing and Midwifery, University of Dublin, Trinity College, Dublin, Republic of Ireland.

Email: $\underline{\text { mccanned@tcd.ie }}$ 


\begin{abstract}
Background: There has been growing attention to addressing the health inequalities and concerns of LGBTQ+ people, with research evidence highlighting areas requiring further attention and development. The distinct concerns of LGBTQ+ people when accessing midwifery care and support is an issue requiring a specific focus to ensure needs are met effectively.
\end{abstract}

Aim: The aim of this systematic review was to critically appraise and synthesise the best available evidence regarding the views and experiences of LGBTQ+ people in relation to midwifery care and supports.

Method: A systematic review was undertaken to identify all relevant studies meeting the inclusion criteria. A total of eleven papers were included in the review, utilising the Preferred Reporting Items for Systematic Reviews and Meta-analyses (PRISMA) method. Methodological quality was evaluated using the Mixed Methods Assessment Tool (MMAT).

Findings: Following data analysis, the themes that emerged were: (i) Contemplating pregnancy and ante-natal experiences, (ii) pregnancy and labour issues and concerns, and (iii) post-natal ongoing care and supports.

Conclusion and implications for practice: It has become apparent from this systematic review that LGBTQ+ individuals have variable experiences when accessing midwifery care and support. Midwifery policies and practice guidelines should be reflective of the distinct needs of LGBTQ+ people and their families and friends. Future studies could focus more on the impact and outcomes of their care experiences within midwifery services.

KEYWORDS: Midwifery; nurse midwife; LGBTQ; care and support; education

\title{
4302 words
}




\section{Introduction}

The term LGBTQ+ will be used throughout this paper as it is widely accepted and encompasses all sexual and gender identities and groups (Formby, 2017; Frediksen-Goldsen, 2016). The provision of accessible healthcare for everyone is of global importance, yet for many, including many LGBTQ+ people, remains elusive (Crowley et al., 2020; De Haven et al., 2020; de Masi et al., 2017). The ability of LGBTQ+ people to access and use healthcare is equally important with efforts being made to support and meet their distinct health needs (Alencar Albuquerque, 2016; Holmes and Beach, 2020; Institute of Medicine 2011; Royal College of Nursing 2016; World Health Organization, 2013a). One of the key midwifery competencies endorsed as essential in a recent study referred to 'the care needs of marginalized and vulnerable populations' (Butler et al., 2018, p175). The guiding principles of midwifery practice include respect and dignity for the person and their family, quality of practice, collaboration with others, professional responsibility and accountability and trust and confidentiality (Butler et al., 2018). However, despite this position, there are significant differences in the experiences of LGBTQ+ people regarding their health needs when accessing and using midwifery services (McManus et al., 2006; Cherguit et al., 2013; Miller and Smith, 2020). The situation is compounded by heteronormative beliefs that individuals fall into distinct and complementary genders of 'man' and 'woman' promoting heterosexuality as the 'normal' or 'preferred' sexual orientation (Mind, 2016). This is exemplified by, for example, assumption that all midwifery service users are heterosexual and is reinforced through written and verbal communication, reference to 'traditional' family structures and legal issues with parenthood (Hammond, 2014, McManus et al., 2006; Richardson et al., 2019).

This is noticeable when LGBTQ+ people use midwifery services before, during and after pregnancy and childbirth where they may be exposed to negative attitudes, reactions and 
actions by some midwives (Hammond, 2014; Stewart and O’Reilly, 2017). Anxiety due to the fear of disclosure of sexual orientation and misunderstanding of partner involvement appears to be commonplace leading to concerns of discrimination and marginalisation (Hammond, 2014; McManus et al., 2006). Furthermore, the wider issues regarding the needs of transgender people and the complexities of surrogacy concerns present additional challenges for some LGBTQ+ people (Riggs et al., 2015). Research to date highlights the importance of including LGBTQ+ health-related issues within undergraduate healthcare education and professional training programmes (McCann and Brown, 2018). The reviewers reported the implications for education and training, clinical practice and research. However, only one paper referred to obstetrical nurse education with no specific reference of midwifery services or the view and experiences of LGBTQ+ people (Echezona-Johnson, 2017). Therefore, it is the aim of this systematic review to present the views and experiences of LGBTQ+ people in relation to midwifery care and support and make recommendations in relation to midwifery policy, education, practice development and future research.

\section{Methods}

The objectives of this systematic review were to:

(i) identify the views of LGBTQ+ people when accessing midwifery care and support;

(ii) identify the experiences of LGBTQ+ people when accessing midwifery care and support;

(iii) highlight areas where developments are required to improve the care and support of LGBTQ+ people when accessing midwifery services.

The PROSPERO and Cochrane Databases were reviewed prior to commencing the systematic review to determine whether a similar review was in existence. No such reviews were identified. The review followed the Preferred Reporting Items for Systematic Reviews and 
Meta-analyses (PRISMA-S) guidelines (Rethlefsen et al. 2021). As the current systematic review involved a critical appraisal of the available research evidence ethical approval was not required.

Search strategy

An expert subject librarian assisted with formulating the review search strategy. The databases used in the search were CINAHL, APA PsycINFO, MEDLINE, Web of Science, SCOPUS and Maternity and Infant Care. The search terms used included midwive*, midwif*, lesbian, gay, bisex*, transgender, queer, and intersex*. The search terms views, experiences and perceptions were also used. Boolean operators AND/OR were utilised. The data were published from inception to July 2021. Hand searching of study reference lists and Google Scholar was used to identify potential additional papers for inclusion. The search strategies of the databases used is shown in Table 1.

****Insert Table 1 here***

\section{Inclusion and exclusion criteria}

The inclusion criteria were limited to academic journals and peer reviewed empirical studies written in English. Studies were included that focused specifically on the views and experiences of LGBTQ+ people when accessing and using midwifery services. Studies were excluded if they did not focus exclusively on the views and experiences of LGBTQ+ people in relation to midwifery care and supports; were not empirical research; were grey literature and theses; and were not published in English.

Following the identification of potential papers, the studies were initially screened using the inclusion and exclusion criteria. The study title and abstract were considered by two reviewers after the removal of duplicates. The full text papers were retrieved and then 
independently screened and the inclusion and exclusion checklist completed. The reviewers determined through consensus which papers were finally included in the full review.

\section{Data extraction and analysis}

Following critical appraisal data were extracted regarding country, aim, design, sample characteristics, study method, findings and recommendations. The data were subjected to thematic analysis and the identified themes arranged into concepts identified from across and within the included studies (Clarke and Braun, 2017). Covidence Systematic Review Software was used within the review process (Veritas Health Innovation, 2020). The themes were initially identified individually, then collectively verified and approved by the research team, hence addressing the potential for reviewer bias (Terry et al., 2017).

\section{Quality assessment}

To reduce the potential of bias, two authors individually quality assessed all papers presented in Table 2 using the mixed methods appraisal tool (MMAT) (Hong et al., 2018). A third reviewer verified the quality appraisal process. A category of 'low' 'medium' or 'high' was assigned to each study following the application of the MMAT appraisal questions. All of the included studies were scored 'high' in terms of quality as set out in Table 2.

*** Insert Table 2 here ***

\section{Findings}

The search process identified 301 papers including those sourced through manual searching. A total of 90 remained following the removal of duplicates which were then screened by title and abstract applying the inclusion and exclusion criteria. This left a total of 11 papers which were 
critically appraised by the research team and agreement reached for their inclusion in the systematic review.

***Insert Figure 1 here***

\section{Study characteristics}

The 11 papers that met the aim of the review are detailed in Table 3, with all papers utilising qualitative methodological approaches. Data collection methods involved individual interviews and focus groups. Studies were conducted in Sweden $(n=5)$, the United States $(n=2)$, Norway $(n=1)$ and the UK $(n=3)$. The sample sizes ranged from 6 to 60 participants.

*** Insert Table 3 here ***

\section{Data analysis and synthesis}

A total of three key themes were identified following the systematic analysis of the studies: (i) contemplating pregnancy and ante-natal experiences, (ii) pregnancy and labour issues and concerns, and (iii) post-natal ongoing care and supports.

\section{Contemplating pregnancy and ante-natal experiences}

It is apparent from the views and experiences of LGBTQ+ people that midwives attempt to use their knowledge and skills to deliver safe, competent, compassionate and respectful care tailored to the unique needs and circumstances of all individuals in their care and their family. This is viewed as important by LGBTQ+ people as the constellation of family have now evolved beyond the traditionally accepted and understood conceptualisation of 'family' (Röndahl et al., 2009). Often however, LGBGTQ+ people continue to receive care that is delivered within a dominant heteronormative culture with the distinct needs and concerns of lesbian, bisexual and transgender people remaining hidden, ignored and poorly understood 
(Dibley 2009; Klittmark et al., 2019; Larsson and Dykes, 2009; Lee et al., 2011; Malmquist, 2019; Renaud, 2007; Röndahl et al., 2009; Wilton \& Kaufmann, 2001). It was seen as crucial for some that they identify a 'lesbian friendly' health provider to be involved from the outset. Other LGBTQ+ study participants had concerns around surrogacy, trust and legal issues such as parental rights (Renaud, 2007). In some studies, the LGBTQ+ participants had negative past healthcare experiences and were reluctant to divulge their sexual identity for fear of discrimination and the threat of the provision of appropriate care and supports (Dibley 2009; Malmquist, 2019; Röndahl et al. 2009; Spidsberg 2007; Wilton and Kaufmann 2001). The importance of recognising, valuing and fully involving co-mothers in the ant-natal process and beyond was stressed by some lesbian participants (Erlandsson et al., 2010; Larsson and Dykes, 2009; Renaud, 2007). To address these concerns, appropriate and responsive pre-natal care and education is required for all same-sex couples and co-mothers (Erlandsson et al., 2010). Additionally, in parenting classes, the use of appropriate pronouns and inclusive language and terminology were seen as imperative in the provision of more culturally sensitive care (Röndahl et al. 2009; Spidsberg, 2007).

LGBTQ+ people viewed it as necessary for midwives to recognise and respond appropriately to the support needs of different families with diverse experiences and requirements. This was viewed as necessary by LGBTQ+ people to enable midwives to address their own preconceptions and assumptions of appropriate healthcare delivery regarding nongender conforming individuals, thereby proactively addressing issues related to heteronormativity, minority stress and discrimination (Dibley et al., 20091 Ellis et al., 2015; Lee et al., 2011; Larsson and Dykes, 2009; Malmquist 2019, Renaud 2007; Röndahl et al., 2009). It was highlighted by some lesbian, bisexual and trans participants that midwives need to demonstrate sensitivity, diplomacy and understanding of their unique needs throughout the entire care journey from pre-pregnancy, antenatal care, labour, postnatal care and parenting 
and on-going care and support (Röndahl et al., 2009; Spidsberg 2007). In a Swedish study it was highlighted by some participants that midwives lacked knowledge about the psychosocial support needs arising from previous miscarriages and infertility, an issue that needs to be recognised and addressed (Klittmark et al., 2019). Shortcomings were identified in the education of midwives by lesbian participants in one study describing an opportunity of 'providing education to midwives' as experts by experience (Wilton and Kaufmann, 2001; Dibley 2009). Additionally, an evolving issue identified by some study participants related to the needs of male identified and gender variant gestational parents and the recognition and responses required from midwives (Ellis et al. 2015).

\section{Pregnancy and labour issues and concerns}

A concern experienced by some study participants during pregnancy and labour related to fear of discrimination and prejudice from midwives that would negatively impact on the care and support received (Dibley 2009; Klittmark et al., 2019; Lee et al., 2011; Larsson and Dykes, 2009; Malmquist, 2019). The concerns led to minority stress and hypervigilance, with some participants in one study highlighting issues related to homophobia and transphobia (Malmquist, 2019). For lesbians, there were concerns highlighted regarding what was termed 'inappropriate voyeurism', with some midwives being perceived as overly curious and intrusive, leading to feelings of discomfort and embarrassment (Wilton and Kaufmann, 2001). In another study undertaken in the United States involving male identified and gender-variant and gestational parents, there was a feeling of isolation and loneliness during their pregnancy and labour experience, with an opportunity for midwives to recognise and respond to their particular needs (Ellis et al., 2015). Importantly, LGBTQ+ people expressed a desire to be treated with respect and receive 'the same as any other patient', with their privacy respected, thereby avoiding an over focus on their sexuality rather than their specific care and support 
needs (Larsson and Dykes, 2009; Malmquist, 2019). As with prenatal and postnatal experiences, the issue of heteronormativity was evident during labour, a situation further compounded by the use of language and documentation that was not reflective of the diversity of needs of LGBTQ+ people (Renaud, 2007; Röndahl et al., 2009; Spidsberg, 2007).

In a Swedish study involving lesbians, bisexuals and trans participants, fear of childbirth (FOC) was apparent for some. The participants expressed concerns regarding a perceived lack of support from midwives in labour units, with specific fears related to blood, injuries and death. For some partners, there was an assumption that they would be present throughout, despite an expressed FOC (Malmquist, 2019). In another study involving lesbian couples $(n=6)$, participants evidenced care that they found to be 'rough' and insensitive, leading to some hiding their sexual identity (Spidsberg, 2007). In a Swedish study involving LGBTQ+ people, some participants detailed services inadequacies including 'mistreatment' and 'judgmental attitudes.' However, for other participants, they particularly valued the continuous presence of a midwife during labour (Klittmark et al. 2019). In another study, participants evidenced care and support that was positive, highlighting their desire to be treated the same as any other pregnant person (Wilton and Kaufmann, 2001).

\section{Post-natal ongoing care and supports}

A range of issues were identified regarding the role of midwives postnatally in the provision of ongoing care and support. In a UK study involving lesbians $(n=50)$, a significant number of the sample $(n=41)$ reported being satisfied with their postnatal care and experience (Wilton \& Kaufmann, 2001). In contrast, some new lesbian mothers highlighted the need for midwives to proactively provide essential parenting education and postnatal care that takes account of their individual circumstances and needs (Renaud, 2007; Röndahl et al., 2009). In one study, the specific needs of two lesbian parents when breast-feeding was identified as an issue that needs 
to be more fully understood and addressed by midwives (Renaud, 2007). The situation was further compounded by a recurring issue across a number of the studies focused on the need to address the use of heteronormative language that extended on into postnatal care. The use of heteronormative language and presumptions by some midwives was viewed as creating a further barrier that inhibited the provision of person and family-centered care, ignoring individual circumstances and needs (Klittsmark et al., 2019; Lee et al., 2011; Larsson \& Dykes, 2009; Malmquist, 2019; Dibley 2009; Röndahl et al., 2009; Wilton \& Kaufmann, 2001). While it was acknowledged by study participants that some midwives sought to be inclusive and respectful of the needs of lesbians postnatally, it was suggested that further education was necessary to ensure they fully appreciated their distinct and specific needs postnatally (Dibley 2009; Röndahl et al., 2009). From the perspective of male and gender-variant gestational parents, the need for further education regarding their parenting support needs postnatally was also identified (Ellis et al., 2015). The needs of same sex co-parents who require support to adapt of their new parental role was also identified as an area in need of education and practice development (Larsson \& Dykes 2009; Röndahl et al., 2009; Erlandsson et al., 2010).

\section{Discussion}

As far as the authors are aware, this systematic review is the first to focus exclusively on the views and experiences of LGBTQ+ people regarding the care and supports provided by midwives. The implications for midwifery policy, practice, education and future research opportunities are discussed.

\section{Issues for midwifery policy}

The literature identified within this systematic review spans over a twenty-year period. During this time there have been major legislative developments that have recognised and strengthened 
the position of LGBTQ + people across the world (World Health Organisation, 2013). Fundamental human rights and equality directives to tackle discrimination, marginalization, and social inclusion have been enshrined within legislation. These positive legislative developments include human rights, civil partnership, marriage equality, adoption and fostering (Henry and Wetherell, 2017). However, despite the development of a legislative framework aimed at protecting LGBTQ+ people there are continued challenges within healthcare including maternity care. The International Confederation of Midwives (ICM) clearly states the importance of midwives recognizing, advocating for and respecting the human rights of all people in its International Code of Ethics for Midwives (2014). The ICM is clear in its recommendation that midwives should welcome all those who need midwifery care and provide them with compassionate, culturally safe care regardless of their gender identity, gender expression or sexual orientation (ICM, 2017). In the UK the Nursing and Midwifery Council does not specifically make reference to LGBTQ+ people or issues within 'The Code', however, it contains clear standards highlighting the need for care and support to be 'person centered'. These standards include to 'treat people with kindness, respect and compassion', 'recognise diversity' and 'challenge discriminatory attitudes' and upon which all midwifery practice must be based (2015).

Despite these national and international standards there remains a lack of either local or national maternity guidelines to reflect the unique needs of the LGBTQ+ community. This potentially leads to two issues; The LGBTQ+ community can feel underrepresented by the lack of inclusive policies and guidelines in place to support their care and midwives do not feel adequately prepared, equipped and confident in providing care for LGBTQ+ people without them (Fish, 2010). Since the implementation of the Equality Act in 2010 the health servce in the UK has a legal obligation to take steps towards creating an inclusive and LGBTQ+ friendly 
organization. An appropriate starting point would be to address the lack of clinical and operational guidelines specific to maternity care for LGBTQ+ parents.

\section{Issues for midwifery practice}

This systematic review has highlighted that the needs of LGBTQ+ people when in receipt of midwifery care continues to be provided within a dominant heteronormative culture. The evidence within the review suggests that the distinct needs of LGBTQ+ people either remain hidden are ignored or poorly understood. A key finding of the review is that there are significant gaps in the development of cultural competence related to the health needs of LGBTQ+ in relation to maternity care, similar to other areas of healthcare (Stewart and O'Reilly, 2017). Increasingly identities, families and social structures are complex which requires sophisticated and sensitive awareness by midwives and this now needs to include an understanding of gender and sexuality. Midwives work with all family types, and this means that there is a need to understand the unique health and social issues of all populations, including LGBTQ+ people (Kerppola et al. 2020). Practice should not be based around the assumption that clients are in 'traditional' relationships, or that they identify with traditional gender identities or sexual orientations (Klittmark et al., 2019). This systematic review has identified expressed feelings of isolation and loneliness, minority stress and hypervigilance, fear of childbirth and fear of discrimination and prejudice. It can be damaging and isolating to receive healthcare in a setting that does not recognise, understand and respond to the needs of individual LGBTQ+ and their families who can experience similar isolation and passive or active discrimination on a daily basis (Halkitis and Krause, 2020).

LGBT+ people and their families require individualised care from midwives. The Royal College of Midwives (2000) highlights that working with diversity involves recognizing and understanding individual needs to enable the provision of the same high standard of care for 
all. Providing individualised care is pivotal in improving the experiences for LGBTQ+ parents and reflects their unique needs. The development of midwifery continuity of care models increases the likelihood of developing a trusting relationship and can facilitate proactive and appropriate culturally sensitive care to LGBTQ+ parents (Margolies and Carlton, 2019). It has become evident from this systematic review that using inclusive language and addressing discriminative language will make LGBTQ+ people feel more comfortable and accepted within the maternity setting. The use of preferred pronouns, inclusive language and terminology is imperative in the provision of more culturally competent and inclusive care (Schreuder, 2019). There is a professional responsibility to be informed and to act respectfully towards people who have these identities to ensure they have access to healthcare without discrimination or abuse, to ensure that the health and social needs of LGBTQ+ populations are being sensitively addressed (Colpitts and Gahagan, 2016). The provision of maternity training specific to the needs of LGBTQ+ people, is required that enables midwives to address their own preconceptions and assumptions. Equally, it is important that the latest research evidence informs midwifery practice, thereby responding appropriately to the needs of LGBTQ+ people and their families (Spencer and Yuill, 2018). To date there has been limited research focusing on the views and experiences of LGBTQ+ people when accessing maternity care and is an issue that requires to be addressed. More qualitative research in this area will aid a better understanding of what LGBTQ+ parents and their families require and need from healthcare professionals including midwives (Wilton and Kaufmann, 2001). Identifying themes from the literature is pivotal to inform the development of inclusive practice guidelines and education opportunities and can make positive steps towards creating a more inclusive healthcare system for LGBTQ+ people.

\section{Issues for midwifery education}


In response to the findings of this systematic review of views and experiences of delivery of maternity care to the LGBTQ+ community, it is important that midwifery educators consider education programmes designed to improve standards of maternity care. Enhancements in Continuing Professional Development (CPD) are required along with delivering learning objectives within under and post-graduate midwifery curricula (Wilton \& Kaufmann, 2001). In response to the themes identified in this systematic review, potential aim(s), objectives and assessment strategies for an education program designed to adequately prepare maternity care professionals regarding the needs of childbearing LGBTQ+ people and their families need to be established based on the critical appraisal of the research studies comprising this systematic review, set out in Table 4 .

***Insert Table 4 here***

\section{Future research directions and opportunities}

This systematic review clearly evidences that many LGBTQ+ people, their partners, and families experience disparities in maternity care provision, compared with non-LGBTQ+ populations. With respect to these identified disparities, further research is required to explore and reduce 'stigmatisation' and improve standards of maternity care delivered to childbearing LBTQ+ clients. There is also a need to develop and implement educational programs for maternity care professionals, and measure their impacts upon LGBTQ+ individuals' physical, psychological, and social well-being. Overall, further research is required to improve understandings of the LGBTQ+ persons' specialised needs and develop response interventions to improve standards of care delivered. There is also a dearth of research evidence that has explored gay father surrogacy and their specific needs. Surrogacy is the legal agreement whereby a woman carries a pregnancy for a single gay man or gay couple, who post-birth become the father(s). One successful example of surrogacy in the public domain is Elton John 
and David Furnish, who have two sons' courtesy of a surrogate mother. Arising from the evidence presented in this systematic review, there is a need for further research investigating the views and experiences of gay men as surrogates.

\section{Limitations and strengths}

This is the first systematic review to report on the specific views and experiences of LGBTQ+ people in relation to the care and support provided by midwives. The review provides important directions for midwifery policy, practice and future education initiatives to promote the provision of care and support that is culturally sensitive and appropriate to the needs of LGBTQ+ people and their families. Several limitations have been identified from this review including the limited research concerning, for example, gay fathers as surrogates and studies conducted outside of Europe and North America. There is an absence of longitudinal and multicentre national and international studies and studies focusing on the specific LGBTQ+ subpopulations. The authors sought to be rigorous in the review process with recognising the potential for subjectivity and bias.

\section{Conclusion and implications for practice}

It is apparent from this systematic review that LBT people have variable experiences when accessing midwifery care and support. Midwifery policies and practice guidelines should be reflective of the distinct needs of LGBTQ+ people and their families and friends. While there are examples of good practice, notably related to the issues and concerns of lesbians, there is a need to develop midwifery practice that is reflective of and responsive to their individual requirements and needs. From the available evidence, current education provision appears inconsistent. Hence, there is an opportunity to develop consistent approaches to the inclusion of LGBTQ+ needs and concerns within undergraduate, post-registration and CPD education 
specific to the requirements of midwives. Whilst there is some research evidence on the general healthcare needs of LGBTQ+ people, future studies could focus more on the impact and outcomes on the care experiences within midwifery services.

\section{Ethical approval}

None applicable

\section{Funding sources}

This work was supported by the Burdett Trust for Nursing [grant number: ****].

Declaration of competing interest

None declared 


\section{References}

Alencar Albuquerque, G., de Lima Garcia, C., da Silva Quirino, G., Alves, M. J., Belém, J. M., dos Santos Figueiredo, F. W., da Silva Paiva, L., do Nascimento, V. B., da Silva Maciel, É., Valenti, V. E., de Abreu, L. C., Adami, F. 2016. Access to health services by lesbian, gay, bisexual, and transgender persons: Systematic literature review. BMC International Health and Human Rights, 16 (2), 1-10. doi: 10.1186/s12914-015-0072-9

Butler, M.M., Fullerton, J.T., Aman, C., 2018. Competence for basic midwifery practice: Updating the ICM essential competencies. Midwifery, 66, 168-175.

Cherguit, J., Burns, J., Pettle, S., Tasker, F., 2013. Lesbian co-mothers' experiences of maternity healthcare services. J Adv Nurs, 69, (6), 269-1278.

doi: $10.1111 / \mathrm{j} .1365-2648.2012 .06115 . \mathrm{x}$

Clarke, V., and Braun, V., 2017. Thematic analysis. The Journal of Positive Psychology, 12(3), 297-298.

Colpitts, E., \& Gahagan, J., 2016. "I feel like I am surviving the health care system": understanding LGBTQ health in Nova Scotia, Canada. BMC Public Health, 16(1), 1005.

Crowley, R., Daniel, H., Cooney, T.G. and Engel, L.S., 2020. Envisioning a better US health care system for all: Coverage and cost of care. Annals of Internal Medicine, 172(2Supplement), S7-S32.

De Haven, M.J., Gimpel, N.A., Kitzman, H., 2020. Working with communities: Meeting the health needs of those living in vulnerable communities when Primary Health Care and Universal Health Care are not available. Journal of Evaluation in Clinical Practice, 13.

de Masi, S., Bucagu, M., Tunçalp, Ö., Peña-Rosas, J.P., Lawrie, T., Oladapo, O.T. and Gülmezoglu, M., 2017. Integrated person-centered health care for all women during pregnancy: implementing World Health Organization recommendations on antenatal care for a positive pregnancy experience. Global Health: Science and Practice, 5(2), 197-201.

Dibley, L. B. 2009. Experiences of lesbian parents in the UK: interactions with midwives. Evidence-Based Midwifery, 7(3), 94-101.

Echezona-Johnson, C., 2017. Evaluation of Lesbian, Gay, Bisexual, and Transgender Knowledge in Basic Obstetrical Nursing Education. Nurs Educ Perspect 38, (3), 138-142. doi: 10.1097/01.NEP.0000000000000136.

Ellis, S.A., Wojnar, D.M., Pettinato, M., 2015. Conception, pregnancy, and birth experiences of male and gender variant gestational parents: It's how we could have a family. J Midwifery Womens Health, 60, (1), 62-69. doi:10.1111/jmwh.12213

Erlandsson, K., Linder, H., Häggström-Nordin, E., 2010. Experiences of gay women during their partner's pregnancy and childbirth. Br J Midwifery, 18, (2), 99-103. doi.org/10.12968/bjom.2010.18.2.46407 
Fish, J., 2010. Conceptualising social exclusion and lesbian, gay, bisexual and transgender people: the implications for promoting equity in nursing policy and practice. Journal of Research in Nursing 15(4) 303-12.

Formby E., 2017. How should we 'care' for LGBT+ students within higher education? Pastor Care Educ 35, (3), 203-20. doi.org/10.1080/02643944.2017.1363811

Fredriksen-Goldsen KI., 2016. The future of LGBT+ aging: A blueprint for action in services, policies, and research. Generations 40, (2), 6-15.

Halkitis, P. N., \& Krause, K. D., 2020. Public and Population Health Perspectives of LGBTQ Health. 1-5.

Hammond, C., 2014. Exploring same sex couples' experiences of maternity care. Br J Midwifery, 22, (7), 495-500. Doi.org/10.12968/bjom.2014.22.7.495

Henry, P.J., Wetherell, G., 2017. Countries with greater gender equality have more positive attitiudes and laws concerning lesbians and gay men. Sex Roles 77(7-8) 523-532.

Holmes, N. and Beach, L.B., 2020. Bisexual people's utilization of sexual health services at an LGBTQ community center in Chicago. Journal of Bisexuality, 1-18.

Hong, Q.N., Fàbregues, S., Bartlett, G., Boardman, F., Cargo, M., Dagenais, P., Gagnon, M.P., Griffiths, F., Nicolau, B., O’Cathain, A., Rousseau, M.C., 2018. The Mixed Methods Appraisal Tool (MMAT) version 2018 for information professionals and researchers. Educ Informat, 34, (4), 285-291. doi: 10.3233/EFI-180221

Institute of Medicine, 2011. The Health of Lesbian, Gay, Bisexual, and Transgender People. The National Academies Press, Washington, D.C.

International Confederation of Midwives (ICM), 2014. International Code of Ethics for Midwives. ICM, The Hague, The Netherlands.

International Confederation of Midwives (ICM), 2017. Human Rights of Lesbian, Gay, Bisexual, Transgender and Intersex (LGBTI) People. ICM, The Hague, The Netherlands.

International Confederation of Midwives (ICM), 2019. Essential Competencies for Midwifery Practice: 2018 Update. ICM: The Hague.

Kerppola, J., Halme, N., Perälä, M. L., \& Maija-Pietilä, A., 2020. Empowering LGBTQ parents: How to improve maternity services and child healthcare settings for this community'She told us that we are good as a family'. Nordic Journal of Nursing Research, 40(1), 41-51. 
Larsson, A.K., Dykes, A.K., 2009. Care during pregnancy and childbirth in Sweden: Perspectives of lesbian women. Midwifery, 25, (6), 682-690.

Doi.org/10.1016/j.midw.2007.10.004

Lee, E., Taylor, J., \& Raitt, F. 2011. 'It's not me, it's them': How lesbian women make sense of negative experiences of maternity care: a hermeneutic study. Journal of Advanced Nursing, 67(5), 982-990.

Malmquist, A., Jonsson, L., Wikström, J., Nieminen, K., 2019. Minority stress adds an additional layer to fear of childbirth in lesbian and bisexual women, and transgender people. Midwifery, 79, 102551. doi.org/10.1016/j.midw.2019.102551

Margolies, L., \& Brown, C. G., 2019. Increasing cultural competence with LGBTQ patients. Nursing 49(6), 34-40.

McCann, E., Brown, M., 2018. The inclusion of LGBT+ health issues within undergraduate healthcare education and professional training programmes: A systematic review. Nurse Educ Today, 64, 204-214. doi.org/10.1016/j.nedt.2018.02.028

McManus, A.J., Hunter, L.P., Renn, H., 2006. Lesbian experiences and needs during childbirth: Guidance for health care providers. J Obstet Gynecol Neonatal Nurs, 35, (1), 13 23. doi.org/10.1111/j.1552-6909.2006.00008.x

Miller, E., Smith, C., 2020. If We Don't Ask, Why Would They Tell? Provider and staff perceptions of LGBTQ and gender minority women seeking services in Women's Health. Penn State Journal of Medicine. 15,1.

Mind, 2016. Lesbian, gay, bisexual, trans and queer good practice guide: Guidance for service providers on how to develop $L G B T Q+$ affirmative practices. Retrieved from www.mind.org.uk/media-a/4687/mind-lgbtqplusguide-2016-webres.pdf

Nursing and Midwifery Council, 2015. The Code 'Professional standards of practice and behaviour for nurses, midwives and nursing associates'. NMC, London.

Renaud, M.T., 2007. We are mothers too: Childbearing experiences of lesbian families. J Obstet Gynecol Neonatal Nurs, 36, (2), 190-199. doi.org/10.1111/j.1552-6909.2007.00136.x

Rethlefsen, M.L.; Kirtley, S.; Waffenschmidt, S.; Ayala, A.P.; Moher, D.; Page, M.J.; Koff J.B. 2021. PRISMAS: An extension to the PRISMA Statement for Reporting Literature Searches in Systematic Reviews. Systematic Reviews 10, 1-9.

Richardson, B., Price, S., Campbell-Yeo, M., 2019. Redefining perinatal experience: A philosophical exploration of a hypothetical case of gender diversity in labour and birth. J Clin Nurs, 28, (3-4), 703-710. doi.org/10.1111/jocn.14521

Riggs, D.W., Due, C., Power, J., 2015. Gay men's experiences of surrogacy clinics in India. J Fam Plann Reprod Health Care, 41, (1), 48-53. doi:10.1136/jfprhc-2013-100671 
Röndahl, G., Bruhner, E., Lindhe, J., 2009. Heteronormative communication with lesbian families in antenatal care, childbirth and postnatal care. J Adv Nurs, 65, (11), 2337-2344. doi.org/10.1111/j.1365-2648.2009.05092.x

Royal College of General Practitioners (Northern Ireland), 2015. Guidelines of the care of Lesbian, Gay, Bisexual Patients in Primary Care. Royal College of General Practitioners, Belfast.

Royal College Midwives (RCM), 2000. Maternity Care for Lesbian Mothers. RCM, London

Royal College of Nursing, 2016. Caring for Lesbian, Gay, Bisexual and Trans Clients or Patients: Guide for Nurses and Health Care Support Workers on Next-of Kin Issues. RCN, London.

Royal College of Nursing, 2017. Fair care for trans patients: A RCN guide for nursing and health professionals. RCN, London.

Schreuder, M. C., 2019. Safe spaces, agency, and resistance: A metasynthesis of LGBTQ language use. Journal of LGBT Youth, 1-17.

Spencer, R. L., \& Yuill, O. (2018). Embedding evidence-based practice within the preregistration midwifery curriculum. British Journal of Midwifery, 26(5), 338-342.

Spidsberg, B.D., 2007. Vulnerable and strong-lesbian women encountering maternity care. J Adv Nurs, 60, (5), 478-486. doi.org/10.1111/j.1365-2648.2007.04439.x

Stewart, K., O'Reilly, P., 2017. Exploring the attitudes, knowledge and beliefs of nurses and midwives of the healthcare needs of the LGBTQ population: An integrative review. Nurse Educ Today, 53, 67-77. dx.doi.org/10.1016/j.nedt.2017.04.008

Terry, G., Hayfield, N., Clarke, V., Braun, V., 2017. Thematic analysis. The Sage handbook of qualitative research in psychology, 17-37.

Veritas Health Innovation. Covidence Systematic Review Software. Melbourne, Australia. Available online: www.covidence.org (accessed on 13 August 2020)

Wilton, T., Kaufmann, T., 2001. Lesbian mothers' experiences of maternity care in the UK. Midwifery, 17, (3), 203-211. doi.org/10.1054/midw.2001.0261

World Health Organisation, 2013a. Addressing the Causes of Disparities in Health Service Access and Utilization for Lesbian, Gay, Bisexual and Transgender (LGBTQ) Persons. WHO, Geneva.

World Health Organization, 2013b. WHO Recommendations: Postnatal Care of the Mother and Newborn. WHO, Geneva. 
Table 1: Search Results

\begin{tabular}{|c|c|c|c|c|c|}
\hline Database & Search Term 1 & Search Term 2 & Search Term 3 & Search Term 4 & Search Term 5 \\
\hline & $\begin{array}{l}\text { "midwive*" OR } \\
\text { "midwif*" }\end{array}$ & $\begin{array}{l}\text { "lesbian" OR gay" OR } \\
\text { "bisex*” OR } \\
\text { "transgender" OR “queer" } \\
\text { OR "intersex*” }\end{array}$ & $\begin{array}{l}\text { Search Term } 1 \text { AND } \\
\text { Search Term } 2\end{array}$ & $\begin{array}{l}\text { "views" OR } \\
\text { "experiences" OR } \\
\text { "perceptions" }\end{array}$ & $\begin{array}{l}\text { Search Term } 3 \text { AND } \\
\text { Search Term } 4\end{array}$ \\
\hline CINAHL & 45,204 & 21,907 & 128 & 599,914 & 29 \\
\hline PsycINFO & 67,399 & 39,092 & 120 & 1,276015 & 70 \\
\hline MEDLINE & 83,461 & 41,590 & 159 & 1,624250 & 84 \\
\hline PubMed & 76,526 & 54,644 & 184 & 2,182845 & 70 \\
\hline SCOPUS & 47,076 & 66,676 & 57 & 4,215276 & 31 \\
\hline Maternity \& Infant Care & 36,769 & 340 & 73 & 15,833 & 17 \\
\hline Hand search of ref lists & --- & --- & 3 & --- & --- \\
\hline Total & 356,435 & 224,249 & 724 & 9, 914133 & 301 \\
\hline
\end{tabular}


Table 2: Methodological quality of qualitative studies using MMAT (Hong et al. 2018)

\begin{tabular}{|l|c|c|c|c|c|c|c|}
\hline & Q1 & Q2 & Q3 & Q4 & Q5 & Total & $\begin{array}{l}\text { Ratings: } \\
\text { (5-high, 3-4 } \\
\text { medium, <3 } \\
\text { low) }\end{array}$ \\
\hline Dibley (2009) & & & & & & & \\
\hline Ellis et al. (2015) & Y & Y & Y & Y & Y & 5 & H \\
\hline Eriandsson et al. (2010) & Y & Y & Y & Y & Y & 5 & H \\
\hline Klittmark et al. (2019) & Y & Y & Y & Y & Y & 5 & H \\
\hline Larsson and Dykes (2009) & Y & Y & Y & Y & Y & 5 & H \\
\hline Lee et al. (2011) & Y & Y & Y & Y & Y & 5 & H \\
\hline Malmquist (2019) & Y & Y & Y & Y & Y & 5 & H \\
\hline Renaud (2007) & Y & Y & Y & Y & Y & 5 & H \\
\hline Röndahl et al. (2009) & Y & Y & Y & Y & Y & 5 & H \\
\hline Spidsberg (2007) & Y & Y & Y & Y & Y & 5 & H \\
\hline Wilton and Kaufmann (2001) & Y & Y & Y & Y & Y & 5 & H \\
\hline
\end{tabular}

$\mathrm{Y}=\mathrm{yes}$, indicates a clear statement appears in the paper which directly answers the question;

$\mathrm{N}=$ no, indicates the question has been directly answered in the negative in the paper;

$\mathrm{CT}=$ can't tell, indicates there is no clear statement in the paper that answers the question

Critical appraisal questions were as follows:

1. Is the qualitative approach appropriate to answer the research question?

2. Are the qualitative data collection methods adequate to address the research question?

3. Are the findings adequately derived from the data?

4. Is the interpretation of results sufficiently substantiated by data?

5. Is there coherence between qualitative data sources, collection, analysis and interpretation? 
Table 3: Papers included in the review $(n=11)$

\begin{tabular}{|c|c|c|c|c|c|}
\hline $\begin{array}{l}\text { Study Citation } \\
\text { and Country }\end{array}$ & Aims & Sample & Methods & Key Findings & Recommendations \\
\hline $\begin{array}{l}\text { Dibley (2009) } \\
\text { (United Kingdom) }\end{array}$ & $\begin{array}{l}\text { Identify the experiences } \\
\text { of lesbian parents and } \\
\text { their interactions with } \\
\text { midwives. }\end{array}$ & Lesbian women $(\mathrm{n}=10)$ & $\begin{array}{l}\text { Qualitative: } \\
\text { Interviews } \\
\text { Phenomenological } \\
\text { hermeneutical } \\
\text { analysis }\end{array}$ & $\begin{array}{l}\text { Narrative accounts were given of } \\
\text { both positive and negative } \\
\text { experiences of midwifery care. Some } \\
\text { midwives were supportive and } \\
\text { inclusive. Others found difficulty to } \\
\text { provide appropriate women-centred } \\
\text { care for lesbians. Heterosexism and } \\
\text { homophobia is apparent within some } \\
\text { areas of midwifery practice. }\end{array}$ & $\begin{array}{l}\text { Midwives require access to } \\
\text { information and practice } \\
\text { development to improve quality } \\
\text { of care provided to lesbians when } \\
\text { accessing maternity services. }\end{array}$ \\
\hline $\begin{array}{l}\text { Ellis et al., (2015) } \\
\text { (United States) }\end{array}$ & $\begin{array}{l}\text { Explore the experiences } \\
\text { of conception, } \\
\text { pregnancy and } \\
\text { childbirth of male and } \\
\text { gender-variant } \\
\text { gestational parents who } \\
\text { have undergone social } \\
\text { or medical gender } \\
\text { transition prior to } \\
\text { pregnancy. }\end{array}$ & $\begin{array}{l}\text { Male-identified or } \\
\text { gender-variant gestational } \\
\text { parents }(n=8)\end{array}$ & $\begin{array}{l}\text { Qualitative: } \\
\text { Interviews } \\
\text { Content analysis }\end{array}$ & $\begin{array}{l}\text { Some males who had undergone } \\
\text { social or medical gender transition } \\
\text { experienced loneliness and complex } \\
\text { internal and external processes of } \\
\text { navigating identity from planning, } \\
\text { pre-conception, pregnancy and birth, } \\
\text { and parenting. }\end{array}$ & $\begin{array}{l}\text { Training to be provided to all } \\
\text { professionals throughout the } \\
\text { gestational parenting continuum. } \\
\text { There should be proper use of } \\
\text { preferred name and pronouns and } \\
\text { increased discussions on privacy } \\
\text { issues. Need to develop models } \\
\text { of an integrated gender-variant } \\
\text { parental roles. }\end{array}$ \\
\hline $\begin{array}{l}\text { Erlandsson et al., } \\
\text { (2010) } \\
\text { (Sweden) }\end{array}$ & $\begin{array}{l}\text { Explore the experiences } \\
\text { of co-mothers during } \\
\text { their partner's } \\
\text { pregnancy, childbirth } \\
\text { and the postnatal } \\
\text { period. }\end{array}$ & $\begin{array}{l}\text { Co-mothers of lesbians } \\
(n=6)\end{array}$ & $\begin{array}{l}\text { Qualitative: } \\
\text { Interviews } \\
\text { Content analysis }\end{array}$ & $\begin{array}{l}\text { The importance of midwives } \\
\text { recognising co-mothers as parents. } \\
\text { There are differences in the needs of } \\
\text { co-mothers and fathers-to-be such as } \\
\text { questions asked and support needed. } \\
\text { Appropriate pre-natal care needed } \\
\text { for same-sex couples including } \\
\text { education classes for co-mothers. } \\
\text { Lack of co-operation experienced by } \\
\text { some. }\end{array}$ & $\begin{array}{l}\text { Recognition required of the co- } \\
\text { mother's parental role. Better } \\
\text { involvement of co-mothers for a } \\
\text { more positive experience. Need to } \\
\text { develop guidelines on gender- } \\
\text { neutral language for use by health } \\
\text { care professionals. Co-mothers } \\
\text { also require additional support to } \\
\text { help post-natal adaptation. } \\
\text { Professionals with experience of } \\
\text { same-sex relationships could }\end{array}$ \\
\hline
\end{tabular}




\begin{tabular}{|c|c|c|c|c|c|}
\hline $\begin{array}{l}\text { Study Citation } \\
\text { and Country }\end{array}$ & Aims & Sample & Methods & Key Findings & Recommendations \\
\hline & & & & & $\begin{array}{l}\text { provide responsive education and } \\
\text { care. }\end{array}$ \\
\hline $\begin{array}{l}\text { Klittmark et al., } \\
\text { (2019) } \\
\text { (Sweden) }\end{array}$ & $\begin{array}{l}\text { Explore LGBTQ } \\
\text { expectant and new } \\
\text { parent's experiences of } \\
\text { reproductive healthcare } \\
\text { in Sweden }\end{array}$ & $\begin{array}{l}\text { LGBTQ expectant or new } \\
\text { parents }(n=12)\end{array}$ & $\begin{array}{l}\text { Qualitative: } \\
\text { Interviews } \\
\text { Content analysis }\end{array}$ & $\begin{array}{l}\text { Some participants described } \\
\text { 'mistreatment and services } \\
\text { inadequacies' when accessing } \\
\text { reproductive healthcare, } \\
\text { experiencing significant } \\
\text { heteronormativity. Some } \\
\text { experienced satisfaction. There is a } \\
\text { need for LGBTQ competent and } \\
\text { responsive reproductive healthcare. }\end{array}$ & $\begin{array}{l}\text { Midwives and reproductive } \\
\text { healthcare professionals would } \\
\text { benefit from education and } \\
\text { interventions to develop LGBTQ } \\
\text { competence. There is a need to } \\
\text { develop professional interventions } \\
\text { to enable the transition to } \\
\text { parenthood for LGBTQ parents. }\end{array}$ \\
\hline $\begin{array}{l}\text { Larsson and Dykes } \\
(2009) \\
\text { (Sweden) }\end{array}$ & $\begin{array}{l}\text { Explore the views and } \\
\text { experiences of care of } \\
\text { lesbian women during } \\
\text { pregnancy and } \\
\text { childbirth. }\end{array}$ & Lesbian women $(\mathrm{n}=18)$ & $\begin{array}{l}\text { Qualitative: } \\
\text { Interviews } \\
\text { Content analysis }\end{array}$ & $\begin{array}{l}\text { Recognition and acceptance as } \\
\text { 'normal' family. Heteronormative } \\
\text { assumptions made including the } \\
\text { education provided by midwives. } \\
\text { Midwifery assessment needs to } \\
\text { include lifestyle questions including } \\
\text { different sexual orientations. } \\
\text { Lesbians want to be treated like any } \\
\text { other parent while recognising } \\
\text { differences. Some women were } \\
\text { positive about their care during } \\
\text { pregnancy and childbirth. }\end{array}$ & $\begin{array}{l}\text { All sexual orientations need to be } \\
\text { reflected within education } \\
\text { programmes focusing on } \\
\text { pregnancy, labour and } \\
\text { parenthood. Health professionals } \\
\text { need to avoid heteronormative } \\
\text { assumptions and should ensure } \\
\text { their language and documentation } \\
\text { is reflective of this. }\end{array}$ \\
\hline $\begin{array}{l}\text { Lee et al. (2011) } \\
\text { (United Kingdom) }\end{array}$ & $\begin{array}{l}\text { Identify lesbian } \\
\text { women's interpretations } \\
\text { of maternity care. }\end{array}$ & Lesbian women (n=8) & $\begin{array}{l}\text { Qualitative: } \\
\text { Interviews } \\
\text { Phenomenological } \\
\text { hermeneutical } \\
\text { analysis }\end{array}$ & $\begin{array}{l}\text { Positive and negative midwifery } \\
\text { experiences are described. Lesbian } \\
\text { women make use of a range of } \\
\text { strategies to interpret and make sense } \\
\text { of their negative experiences as a } \\
\text { way to distance themselves from this } \\
\text { negativity and rationalise their } \\
\text { attitudes towards others. }\end{array}$ & $\begin{array}{l}\text { Health professionals need to } \\
\text { recognize the impact of their } \\
\text { responses to sexual orientation } \\
\text { disclosure and ensure that } \\
\text { behaviours and attitudes are } \\
\text { reflective of women-centred and } \\
\text { inclusive policies. }\end{array}$ \\
\hline
\end{tabular}




\begin{tabular}{|c|c|c|c|c|c|}
\hline $\begin{array}{l}\text { Study Citation } \\
\text { and Country }\end{array}$ & Aims & Sample & Methods & Key Findings & Recommendations \\
\hline $\begin{array}{l}\text { Malmquist (2019) } \\
\text { (Sweden) }\end{array}$ & $\begin{array}{l}\text { Explore experiences of } \\
\text { pregnancy, childbirth } \\
\text { and reproductive health } \\
\text { in lesbians, bisexual } \\
\text { women and transgender } \\
\text { people with an } \\
\text { expressed fear of } \\
\text { childbirth. }\end{array}$ & $\begin{array}{l}\text { Lesbians, bisexual } \\
\text { women and transgender } \\
\text { people }(n=17)\end{array}$ & $\begin{array}{l}\text { Qualitative: } \\
\text { Semi-structured } \\
\text { interviews } \\
\text { Thematic analysis }\end{array}$ & $\begin{array}{l}\text { There was fear of prejudicial } \\
\text { treatment in addition to the fear of } \\
\text { childbirth. Concerns regarding care } \\
\text { and support during labour and fear of } \\
\text { childbirth (FOC). Perceived lack of } \\
\text { midwives and support in labour units } \\
\text { lead to fear of insufficient assistance. } \\
\text { Fears of blood, injuries and death } \\
\text { apparent. Assumption, despite FOC, } \\
\text { that partners will be present during } \\
\text { childbirth. Heteronormative } \\
\text { assumptions made adding to } \\
\text { minority stress. Concealing identities } \\
\text { and 'passing' as heterosexual. Guilt, } \\
\text { shame and hyper-vigilance felt by } \\
\text { some LBT participants. }\end{array}$ & $\begin{array}{l}\text { Midwives need to be culturally } \\
\text { competent when meeting the } \\
\text { needs of this group. Has to be } \\
\text { access to education and additional } \\
\text { resources to enable midwives and } \\
\text { others to meet the support needs } \\
\text { of LBT people. Both the needs of } \\
\text { the LBT person and their partner } \\
\text { should be addressed before, } \\
\text { during and after childbirth. The } \\
\text { specific needs of LBT people } \\
\text { regarding FOC should be } \\
\text { recognised and suitable education } \\
\text { provided. Midwives should } \\
\text { proactively address previous } \\
\text { homophobic of transphobic hatred } \\
\text { and negative experiences of } \\
\text { healthcare to address and reduce } \\
\text { FOC. }\end{array}$ \\
\hline $\begin{array}{l}\text { Renaud (2007) } \\
\text { (United States) }\end{array}$ & $\begin{array}{l}\text { Explore lesbians' } \\
\text { experiences of } \\
\text { becoming pregnant, } \\
\text { giving birth, and being } \\
\text { mothers and co- } \\
\text { mothers. }\end{array}$ & Lesbians $(n=60)$ & $\begin{array}{l}\text { Qualitative: } \\
\text { Interviews and focus } \\
\text { groups } \\
\text { Thematic and textual } \\
\text { analysis }\end{array}$ & $\begin{array}{l}\text { Contemplating and planning for } \\
\text { pregnancy and the complexities } \\
\text { involved including who and how? } \\
\text { For example, who could act as sperm } \\
\text { donor? Fear of donors claiming } \\
\text { parental rights. Joy of becoming } \\
\text { pregnant. Choosing a lesbian } \\
\text { friendly health provider was } \\
\text { important. Some homophobia } \\
\text { experienced. Some over- patronising } \\
\text { attitudes and prejudice experienced. } \\
\text { Heteronormative assumptions } \\
\text { apparent in some pre-natal classes. } \\
\text { Examples of caring, sensitivity and } \\
\text { empathy were evident. Incidents }\end{array}$ & $\begin{array}{l}\text { Formal and informal education } \\
\text { about lesbian pregnancy and } \\
\text { parenting should be provided to } \\
\text { midwifery professionals in } \\
\text { hospitals, clinics and education } \\
\text { settings. Continuing education } \\
\text { required regarding the distinct } \\
\text { needs of lesbians. Education } \\
\text { materials needed that reflect the } \\
\text { needs of lesbians. The unique } \\
\text { needs of two lesbian parents when } \\
\text { breast-feeding needs to be } \\
\text { promoted. Visiting policies need } \\
\text { to be inclusive and recognise } \\
\text { extended families and friends. }\end{array}$ \\
\hline
\end{tabular}




\begin{tabular}{|c|c|c|c|c|c|}
\hline $\begin{array}{l}\text { Study Citation } \\
\text { and Country }\end{array}$ & Aims & Sample & Methods & Key Findings & Recommendations \\
\hline & & & & $\begin{array}{l}\text { were also given where essential } \\
\text { teaching and postpartum care was } \\
\text { not provided. }\end{array}$ & \\
\hline $\begin{array}{l}\text { Röndahl et al., (2009) } \\
\text { (Sweden) }\end{array}$ & $\begin{array}{l}\text { Explore lesbian parents' } \\
\text { experience of antenatal, } \\
\text { childbirth and postnatal } \\
\text { care. }\end{array}$ & Mothers $(\mathrm{n}=10)$ & $\begin{array}{l}\text { Qualitative: } \\
\text { Semi-structured } \\
\text { interviews } \\
\text { Thematic analysis }\end{array}$ & $\begin{array}{l}\text { A need for increased knowledge } \\
\text { particularly for midwives in } \\
\text { antenatal care. The use of } \\
\text { heteronormative communication } \\
\text { both verbal and written was } \\
\text { awkward and embarrassing. Lack of } \\
\text { parenthood education available for } \\
\text { lesbians. Midwives displayed } \\
\text { heteronormative traits from ante } \\
\text { natal to post-natal care. Positive } \\
\text { midwifery experiences involved } \\
\text { including the co-parent throughout. } \\
\text { No access to parenthood education. } \\
\text { Need to consider different family } \\
\text { constellations. Patient information } \\
\text { forms were viewed as } \\
\text { heteronormative. Some valued } \\
\text { midwives' education in lesbian- } \\
\text { specific issues. Others of the view } \\
\text { that open mindedness and sensitivity } \\
\text { for all was required. }\end{array}$ & $\begin{array}{l}\text { Need for education on basic } \\
\text { lesbian issues in the midwifery } \\
\text { context especially antenatal care. } \\
\text { Introduction of neutral wording in } \\
\text { forms. Special parenthood } \\
\text { education groups for lesbians } \\
\text { required. Midwives need to focus } \\
\text { on the pregnancy and parenting } \\
\text { rather than sexual orientation. } \\
\text { Parent education needs to be } \\
\text { provided routinely that addresses } \\
\text { the support needs of lesbians. }\end{array}$ \\
\hline $\begin{array}{l}\text { Spidsberg (2007) } \\
\text { (Norway) }\end{array}$ & $\begin{array}{l}\text { Explore the maternity } \\
\text { care experiences of } \\
\text { lesbian couples. }\end{array}$ & Lesbian couples ( $\mathrm{n}=6$ ) & $\begin{array}{l}\text { Qualitative: } \\
\text { Interviews } \\
\text { Phenomenological } \\
\text { hermeneutical } \\
\text { analysis }\end{array}$ & $\begin{array}{l}\text { Lesbians are vulnerable when using } \\
\text { maternity services. The need to be } \\
\text { cared for and communicated with } \\
\text { should be the same as heterosexual } \\
\text { women. Differing views regarding } \\
\text { being open about their lesbian } \\
\text { identity. Use of inclusive language in } \\
\text { parenthood classes by midwives seen } \\
\text { as important. Some reported 'rough' }\end{array}$ & $\begin{array}{l}\text { Midwives need to focus on the } \\
\text { pregnancy and not sexuality per } \\
\text { se. Healthcare providers need to } \\
\text { recognise and respond to the } \\
\text { distinct needs of lesbian women } \\
\text { when accessing maternity care. }\end{array}$ \\
\hline
\end{tabular}




\begin{tabular}{|c|c|c|c|c|c|}
\hline $\begin{array}{l}\text { Study Citation } \\
\text { and Country }\end{array}$ & Aims & Sample & Methods & Key Findings & Recommendations \\
\hline & & & & $\begin{array}{l}\text { and insensitive care from midwives. } \\
\text { Possibility of midwives developing } \\
\text { positive attitudes and confidence. }\end{array}$ & \\
\hline $\begin{array}{l}\text { Wilton and Kaufmann } \\
\text { (2001) (United } \\
\text { Kingdom) }\end{array}$ & $\begin{array}{l}\text { Explore the maternity } \\
\text { care of lesbians. }\end{array}$ & Lesbians $(\mathrm{n}=50)$ & $\begin{array}{l}\text { Qualitative: } \\
\text { Questionnaires } \\
\text { Thematic analysis }\end{array}$ & $\begin{array}{l}\text { Some decided not to disclose their } \\
\text { sexual identity due to continuity of } \\
\text { care issues. Midwifery response to } \\
\text { sexuality disclosure variable from } \\
\text { accepting to judgmental. Some } \\
\text { respondents provided much needed } \\
\text { education to midwives regarding } \\
\text { lesbian mothers. Some midwives } \\
\text { appeared to seek unnecessary } \\
\text { information 'to satisfy their own } \\
\text { curiosity,' where other needs and } \\
\text { concerns were ignored. Midwives } \\
\text { need to be sensitive about sexual } \\
\text { identity disclosure and } \\
\text { confidentiality due to fears of } \\
\text { prejudice. Heteronormativity } \\
\text { apparent in the delivery of ante-natal } \\
\text { parent education groups. Many } \\
\text { reported positive experiences during } \\
\text { intrapartum care that was supportive } \\
\text { and sensitive. Most (n=41) } \\
\text { experiences positive post-natal care. }\end{array}$ & $\begin{array}{l}\text { Midwifery managers should } \\
\text { identify professional training } \\
\text { needs on issues related to } \\
\text { lesbians. Midwives need to be } \\
\text { more open to sexual diversity. } \\
\text { Documentation should be } \\
\text { reviewed to avoid assumptions. } \\
\text { Midwives need to use inclusive } \\
\text { language that is respectful of the } \\
\text { wishes of lesbians. Women-only } \\
\text { antenatal classes should be } \\
\text { provided. All health services need } \\
\text { to have policies that protects } \\
\text { people of all sexual orientations } \\
\text { from discrimination. }\end{array}$ \\
\hline
\end{tabular}


Table 4: Potential aim(s) and objectives for a teaching program designed to improve maternity care delivered to childbearing LGBTQ+ people

\begin{tabular}{|c|c|c|}
\hline & Potential aim(s) and objectives & $\begin{array}{l}\text { Identified in papers in this } \\
\text { systematic review }\end{array}$ \\
\hline Aim & $\begin{array}{l}\text { To equip midwives with knowledge and skills to improve the standard of } \\
\text { maternity care they deliver to LGBTQ+ people, their partner's, and families } \\
\text { across the childbearing spectrum. }\end{array}$ & $\begin{array}{l}\text { Erlandsson et al. (2010) } \\
\text { Larsson \& Dykes (2007) } \\
\text { Renaud (2007) } \\
\text { Röndahl et al. (2009) } \\
\end{array}$ \\
\hline Objective 1 & $\begin{array}{l}\text { Explore the different types of LGBTQ+ families and their distinct needs and } \\
\text { concerns. }\end{array}$ & $\begin{array}{l}\text { Klittmark et al. (2019) } \\
\text { Larsson \& Dykes } \\
\text { (2007) Malmquist (2019) } \\
\text { Renaud (2007) } \\
\text { Röndahl et al. (2009) } \\
\text { Spidsberg (2007) } \\
\text { Wilton \& Kaufmann (2001) }\end{array}$ \\
\hline Objective 2 & $\begin{array}{l}\text { Develop strategies intended to reduce fear of discrimination and prejudice } \\
\text { experienced by childbearing members of the LGBTQ+ populations. }\end{array}$ & $\begin{array}{l}\text { Klittmark et al. (2019) } \\
\text { Larsson \& Dykes (2007) } \\
\text { Malmquist (2019) }\end{array}$ \\
\hline Objective 3 & $\begin{array}{l}\text { Critically discuss what constitutes maternity care professionals 'inappropriate } \\
\text { voyeurism' and develop methods to overcome this. }\end{array}$ & Wilton \& Kaufmann (2001) \\
\hline Objective 4 & $\begin{array}{l}\text { Critically appraise what constitutes respectful, dignified, inclusive, non- } \\
\text { discriminatory, gendered, and gender-neutral language that addresses the full } \\
\text { diversity of LGBTQ+ patients across the childbearing spectrum. }\end{array}$ & $\begin{array}{l}\text { Butler et al. (2018) } \\
\text { Röndahl et al. (2009) } \\
\text { Spidsberg (2007) }\end{array}$ \\
\hline Objective 5 & $\begin{array}{l}\text { Consider approaches that could be used to reduce negative attitudes, } \\
\text { reactions, and actions of maternity care professionals towards childbearing } \\
\text { LGBTQ+ people. }\end{array}$ & $\begin{array}{l}\text { Hammond (2014) } \\
\text { Stewart \& O’Reilly (2017) }\end{array}$ \\
\hline Objective 6 & $\begin{array}{l}\text { Discuss approaches that could be implemented to reduce childbearing } \\
\text { LGBTQ+ individuals' levels of anxiety and fear of disclosure of sexual } \\
\text { orientation and their partner's involvement. }\end{array}$ & $\begin{array}{l}\text { Hammond (2014) } \\
\text { McManus et al. (2005) }\end{array}$ \\
\hline Objective 7 & $\begin{array}{l}\text { Provide an individualised approach to care, which respects } \\
\text { personal experience, needs, beliefs, and values of individual } \\
\text { LGBTQ+ patients. }\end{array}$ & $\begin{array}{l}\text { Hammond (2014) } \\
\text { McManus et al. (2006) } \\
\text { Richardson et al. (2019) } \\
\end{array}$ \\
\hline Objective 8 & $\begin{array}{l}\text { Discuss the advantages and disadvantages of providing a trained } \\
\text { 'LGBTQ+ friendly midwife' to manage childbearing } \\
\text { LGBTQ+ individuals' concerns surrounding surrogacy, trust, legal issues, } \\
\text { parental rights, transgender, surrogacy issues, and other relevant concerns. }\end{array}$ & $\begin{array}{l}\text { Renaud (2007) } \\
\text { Riggs et al. (2015) } \\
\text { Rondahl et al. (2009) }\end{array}$ \\
\hline Objective 9 & $\begin{array}{l}\text { Debate the value of providing a 'peer buddy' to reduce isolation and } \\
\text { loneliness of LGBTQ clients during their childbearing journey. }\end{array}$ & Ellis et al. (2015) \\
\hline Objective 10 & $\begin{array}{l}\text { Design a series of specialized parenthood education classes for LGBTQ } \\
\text { clients and their partners, which extends across the antenatal, intranatal, and } \\
\text { postnatal childbearing spectrum. }\end{array}$ & Ellis et al. (2015) \\
\hline
\end{tabular}


Figure 1: PRISMA Flow Diagram with search results

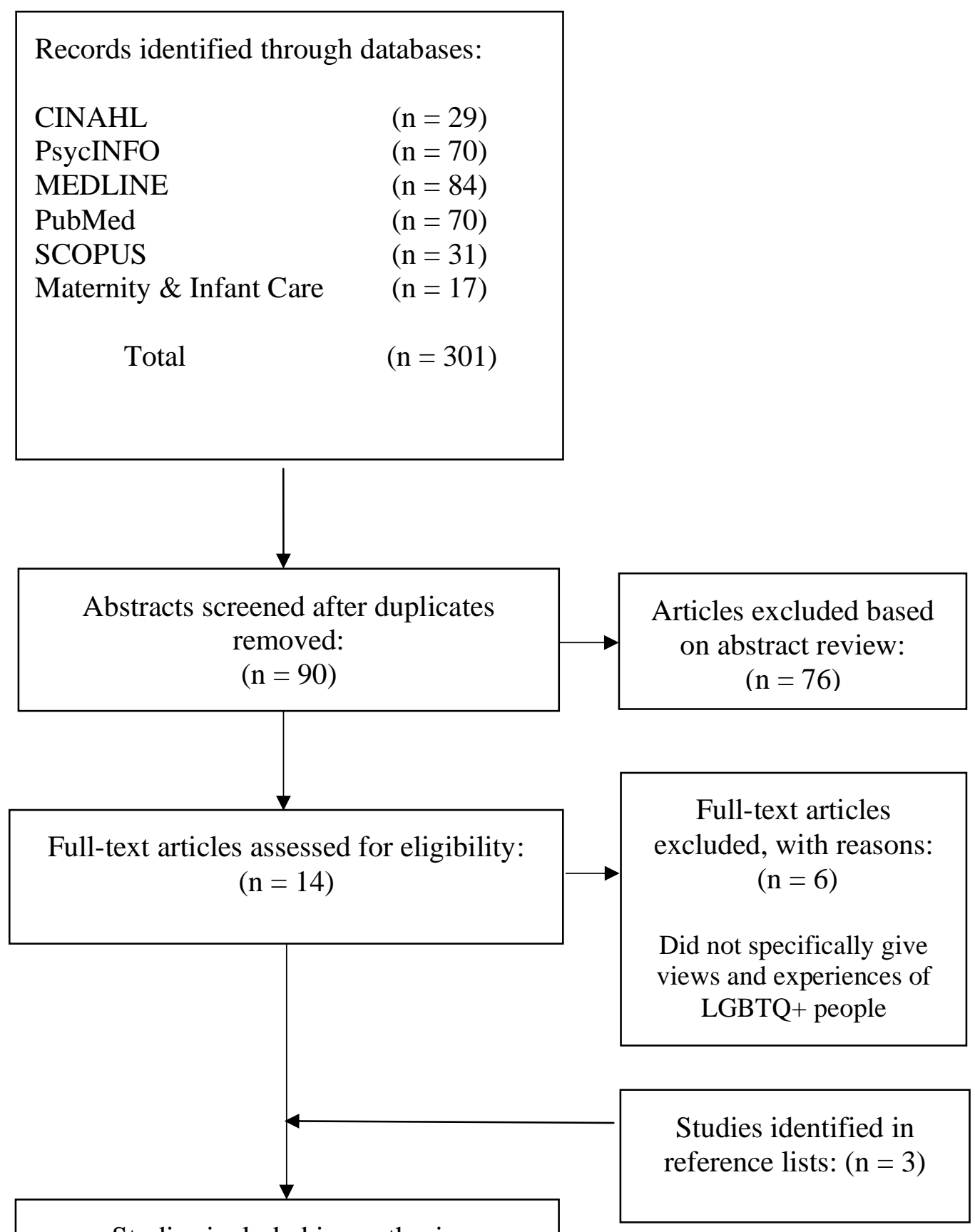

Studies included in synthesis:

$$
\text { ( } \mathrm{n}=11)
$$

